\title{
Ripening Patterns within a Peach as Indicated by Force and Soluble Solids Concentration
}

\author{
B.D. Horton \\ U.S. Department of Agriculture-Agricultural Research Service, Appalachian Fruit Research \\ Station, 45 Wiltshire Road, Kearneysville, WV 25430-9606 \\ Additional index words. maturity stages, Prunus persica
}

\begin{abstract}
Variability in maturity within a peach (Prunus persica, L. Batsch) fruit was estimated by measurements of force and the soluble solids concentration (SSC) at 16 coordinates around the peach at five maturity stages: 1) about one-half final swell (immature); 2) 85\% final swell (green); 3) firm-ripe and similar to chip \#3 of the Clemson Univ. system; 4) firm-ripe and similar to chip \#5; and 5) tree-ripe. Firm-ripe 3 and 4 stages were firm enough to ship, but the tree-ripe stage was too soft. Firmness measured with a 4.7-mm-diameter penetrometer tip from two cultivars indicates a strong trend for the peach tip and cheeks to be firmer than tissue at other coordinates. Coordinates at the equator and around the stem end are generally firmer than coordinates at lat. $45^{\circ} \mathrm{N}$, particularly in stages 3 , 4, and 5. The SSC in juice from a cylinder of fruit adjacent to the puncture was higher at long. $90^{\circ} \mathrm{E}-\mathrm{W}$ than at the sutures and higher at lat. $0^{\circ}$ than at $70^{\circ} \mathrm{S}$. Variance increased for force and decreased for SSC between maturity stages to the firm-ripe stage. The coordinate technique might be used to characterize and select cultivars that would be most suitable for once-over harvests.
\end{abstract}

Success in mechanizing fresh-market peach production depends on the development of cultivars that have a high proportion of fruit in the fresh-market (firm-ripe) shipping stage of maturity from a once-over harvest (Horton, 1985; Peterson et al., 1989; Webb et al., 1973). A peach cultivar characterized by a small SD in firmness among fruit at the cheek, or a narrow range of maturity, would be desirable for a once-over harvest. A cultivar having a narrow maturity range would be easier to sort and would produce more fruit in the shipping range. Daminozide advances maturity of fresh-market peaches by 3 to 7 days (Baumgardner et al., 1972; Byers and Emerson, 1969; Gambrel1 et al., 1967; Sansavini et al., 1970) and is purported to decrease the maturity range of the fresh-market crop. Data by the latter indicate a slight decrease in maturity range for daminozide-treated 'Dixon' peaches. Cultivars vary in the percentage of fruit in the marketable stage, or maturity range, from a once-over harvest (Horton, 1973; Peterson et al., 1989).

Firmness and color are good indices of processing (Tyson et al., 1975) and fresh-market peaches (Delwiche and Baumgardner, 1983, 1985). Color sorting has been expedited by development of the Clemson Univ. peach color chips (Delwiche and Baumgardner, 1983) used for comparison with the greenest portion of the peach. Packinghouse personnel sort fresh-market peaches subjectively by color and discard the green fruit. Overripe peaches are confirmed by their softness. Much of the variability in appearance in fresh-market packs is attributed to grading techniques, because anthocyanin and fuzz frequently mask ground color, lighting arrangements affect color perception, and color perception and sense of touch vary greatly among individuals.

Maturity range values for several peach cultivars were reported by Horton (1973) and Peterson et al. (1989). Difference in values reported might be attributed to procedures used. Harvests were made when the estimated number of green fruit equaled the number of soft ripe fruit. An earlier or later harvest by either might have changed the range of maturity for some of the cultivars. 'Harvester' is noted in the southeastern United States for being a firm, uniform-ripening peach and was reported to have

Received for publication 9 July 1991. Accepted for publication 29 Apr. 1992. The cost of publishing this paper was defrayed in part by the payment of page charges. Under postal regulations, this paper therefore must be hereby marked advertisement solely to indicate this fact. a narrow range of maturity; 94\% in the firm-ripe stage (Horton, 1973). Data from Peterson et al. (1989) show it to be a poor cultivar for a once-over harvest. It is obvious that a better index is needed for making a once-over harvest and for grading in the packing house. Knowledge of the ripening pattern of an individual peach might provide information to improve grading techniques and facilitate research to develop peaches suited for mechanized harvesting and sorting.

A report by Blake and Davidson (1936) indicates that firmness within a peach is variable, just as it is among peaches. They measured firmness changes at coordinates on 'Chinese Cling' peaches during storage from samples that were in the "nearby shipping" maturity stage, or almost soft-ripe. Cheek regions were firmer than the sutures and the region opposite the suture. The objective of this study is to further characterize the ripening pattern of melting flesh peaches according to firmness and soluble solids concentration (SSC) at coordinates of the peach at various maturity stages.

\section{Materials and Methods}

Fruit from 'Elberta Queen' and a white flesh, free stone selection, B11, were sorted by the Clemson Univ. peach color chips (Delwiche and Baumgardner, 1983) into five maturity stages: 1) one-half final swell (immature); 2) about full size (green) with ground color similar to color chip \#1 or \#2;3) shipping-ripe and similar to chip \#3 (firm-ripe 3); 4) shippingripe and similar to chip \#5 (firm-ripe 4); and 5) overripe and similar to chip \#6 (tree-ripe). Sorting was done under coolwhite fluorescent lights. Five peaches in each maturity stage were selected for color uniformity. One fruit in each maturity stage was randomly placed into one of five replications.

Firmness was measured with a McCormick (6111-A Englewood Ave.; Yakima, Wash.) fruit pressure tester model FT 011 (range $5 \mathrm{~kg}$, i.e., $49 \mathrm{~N}$ ) provided with a $4.7-\mathrm{mm}$-diameter tip. The g-mm tip normally used on peaches split the flesh of most immature and some green fruit. The tip was pushed $7 \mathrm{~mm}$ into the pared flesh perpendicular to the fruit surface. Percent SSC was measured with a hand-held refractometer on juice expressed through cheesecloth in a garlic press. Juice was from an 8-mm

Abbreviation: SSC, soluble solids concentration. 
diameter cylinder of tissue extracted down to the pit adjacent to the puncture made by the penetrometer tip.

Measurements were made at 16 coordinates around the peach (Fig. 1); one at the fruit apex, lat. $90^{\circ} \mathrm{N}$ on the flattest side of the stylar scar; five coordinates at lat. $45^{\circ} \mathrm{N}$ round the peach, five places around the equator, and at five coordinates at the stem end, about lat. $70^{\circ} \mathrm{S}$. If the suture represents long. $0^{\circ}$, the five east-west longitudinal coordinates measured were $10^{\circ} \mathrm{E}$ $\mathrm{W}, 90^{\circ} \mathrm{E}-\mathrm{W}$, and $180^{\circ}$. Since the peach is, botanically, a modified leaf, data are presented to resemble a leaf. The leaf apex represents the north pole, lat. $90^{\circ} \mathrm{N}$; the serrated leaf margins represent the suture edges $10^{\circ} \mathrm{E}-\mathrm{W}$; midway between the margins and midrib represents the cheeks, long. $90^{\circ} \mathrm{E}-\mathrm{W}$; and the midrib represents long. 180". The leaf near the petiole represents lat. $70^{\circ} \mathrm{S}$, the stem end of the peach.

Main effects, maturity stages and coordinates, interactions, and contrasts between various coordinates were analyzed by the SAS GLM procedure and means were separated by the least significant difference (LSD) or F test. Variances of force and SSC were transformed to $\log$, (variance +1 ) (Steel and Torrie, 1960), analyzed, and separated by LSD.

\section{Results and Discussion}

Firmness and SSC change with maturity stages (Table 1). Selection B11 was $\approx 10 \mathrm{~N}$ firmer than 'Elberta Queen' within each maturity stage. The SSC increased from the green to the firm-ripe 3 stage and decreased by the tree-ripe stage in 'Elberta Queen'. The difference in flesh firmness between cultivars might be attributed to trying to sort maturity stages of a white flesh peach which is low in the yellow hues of the color chips; but SSC means indicate that maturity stages of the two cultivars were similar.

Firmness in general (Figs. 2 and 3) decreased with each successive maturity stage for both cultivars. Force differences between coordinates diminished in 'Elberta Queen' and presented a more level contour at the tree-ripe stage than those of B11. The small changes in SSC between maturity stage means (Table

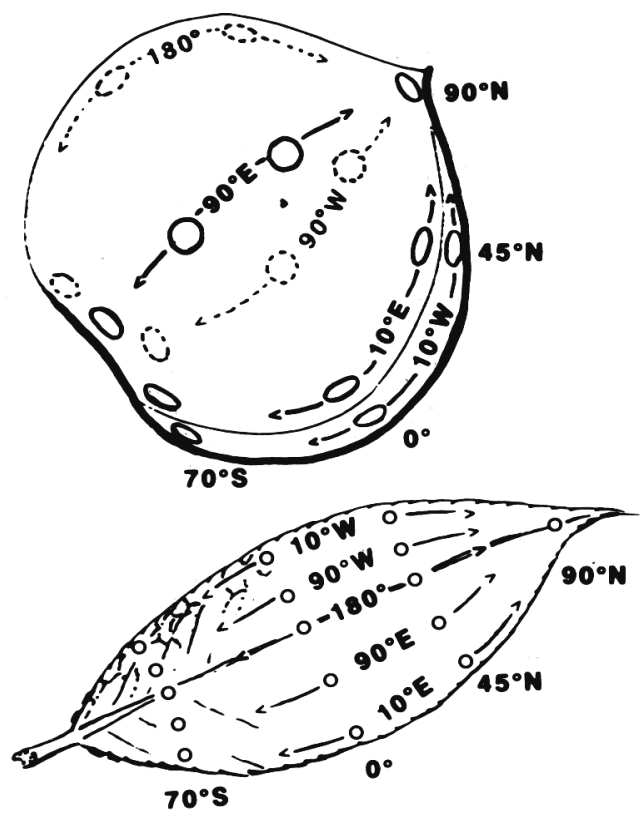

Fig. 1. Diagram of coordinates around a peach where force and SSC were measured and the comparison with a leaf to illustrate the schematic presentation.
Table 1. Flesh firmness as force (N) and SSC (\%) at five peach maturity stages for two cultivars.

\begin{tabular}{|c|c|c|c|c|}
\hline \multirow{3}{*}{$\begin{array}{l}\text { Maturity } \\
\text { stages }^{z}\end{array}$} & \multicolumn{4}{|c|}{ Cultivar } \\
\hline & \multicolumn{2}{|c|}{ Elberta Queen } & \multicolumn{2}{|c|}{ Selection V B-11 } \\
\hline & Force $(\mathrm{N})^{\mathrm{y}}$ & $\operatorname{SSC}(\%)^{\mathrm{y}}$ & Force $(\mathrm{N})$ & SSC \\
\hline 1 & $20.6 \mathrm{a}^{\mathrm{x}}$ & $10.8 \mathrm{c}$ & $30.5 \mathrm{a}$ & $10.7 \mathrm{c}$ \\
\hline 2 & $18.2 \mathrm{~b}$ & $11.0 \mathrm{c}$ & $28.2 \mathrm{~b}$ & $11.3 \mathrm{~b}$ \\
\hline 3 & $11.5 \mathrm{~d}$ & $11.2 b$ & $23.1 \mathrm{~d}$ & $11.2 \mathrm{~b}$ \\
\hline 4 & $11.5 \mathrm{~d}$ & $11.6 \mathrm{a}$ & $23.1 \mathrm{~d}$ & $11.2 \mathrm{~b}$ \\
\hline 5 & $8.0 \mathrm{e}$ & $11.2 \mathrm{~b}$ & $20.1 \mathrm{e}$ & $11.7 \mathrm{a}$ \\
\hline $\mathrm{LSD}_{0.05}$ & 1.43 & 0.23 & 1.10 & 0.38 \\
\hline $\mathrm{CV}$ & 30.9 & 6.7 & 13.7 & 10.6 \\
\hline
\end{tabular}

${ }^{2}$ Maturity stage: $1=$ immature, $2=$ green, $3=$ firm-ripe (Clemson color chip \#3), 4 = firm-ripe (Clemson color chip \#5), and $5=$ treeripe.

${ }^{y}$ Means of 16 coordinates around five peaches in each maturity stage. ${ }^{x}$ Means within columns separated by LSD at $P=0.05$.

\section{ELBERTA QUEEN MEANS}
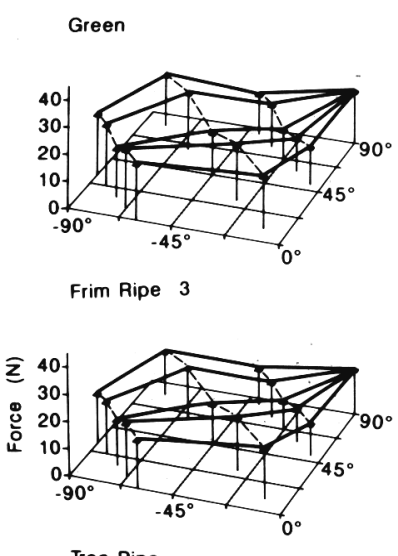

Green
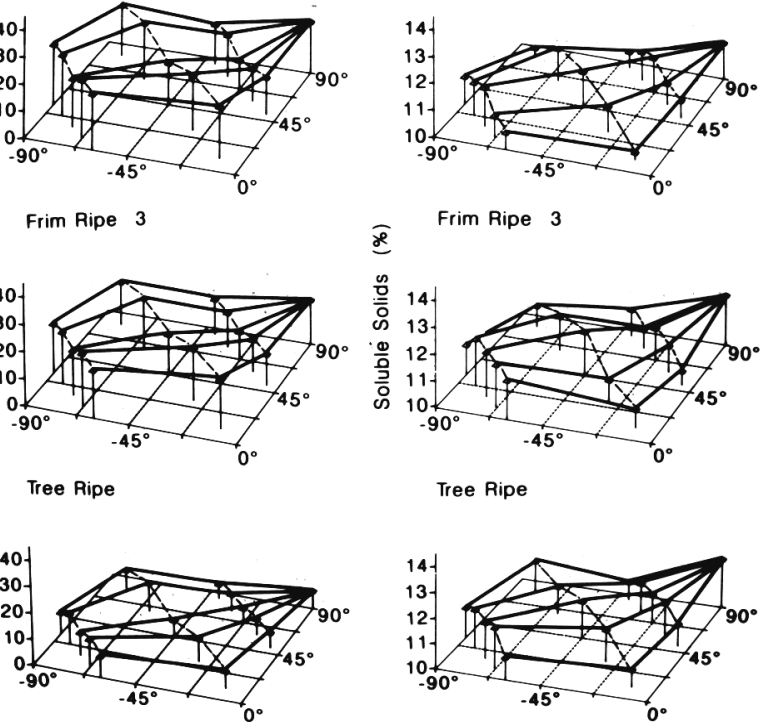

Tree Ripe

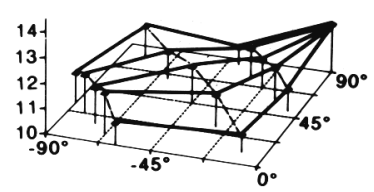

Fig. 2. Schematic presentation of force (newtons) and SSC (\%) means for three maturity stages, green, firm-ripe 3, and tree-ripe, for 'Elberta Queen' peaches. (Variables measured $\approx 70^{\circ} \mathrm{S}$ are plotted at $-60^{\circ}$ to spread the points for better visibility).

1) were not obvious at coordinates in either cultivar (Figs. 2 and 3). Contours of SSC for B11 (Fig. 3) appeared to be more variable than contours for 'Elberta Queen' (Fig. 2).

Force and SSC for certain regions and coordinates that appeared to be different were evaluated by contrasts (Tables 2 and 3). While these contrasts were not statistically rigorous, they indicated regions of the peach that ripened sooner, or later, than the rest of the fruit. Resistance of both cultivars appeared to be higher at $90^{\circ} \mathrm{N}$ and at the coordinates long. $90^{\circ} \mathrm{E}-\mathrm{W}$ with lat. $0^{\circ}$ (center of cheeks) than at other coordinates (Figs. 2 and 3), but according to $\mathrm{F}$ values by contrasts it was not. In 'Elberta Queen', long. $90^{\circ} \mathrm{E}-\mathrm{W}$ was firmer than long. $180^{\circ}$ in stages firm-ripe 4 and tree-ripe (Table 2). 'Elberta Queen' was firmer at $90^{\circ} \mathrm{N}$ (tip) than at any other coordinates (except cheeks) combined. The force required at lat. $0^{\circ}$ and $70^{\circ} \mathrm{s}$ was generally higher than at lat. $45^{\circ} \mathrm{N}$, particularly for the firm-ripe and treeripe stages. The B11 selection was more uniform in firmness 
B 11 SELECTION MEANS
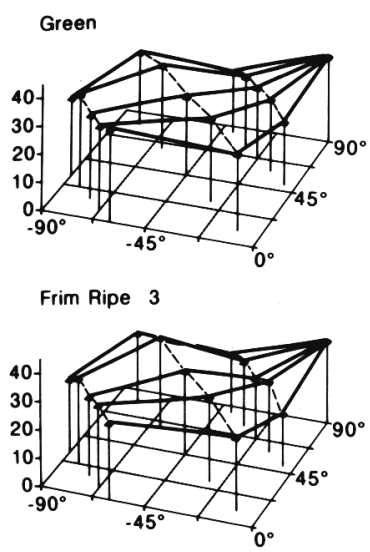

Tree Ripe
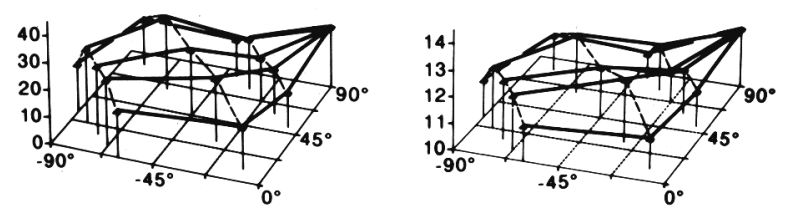

Fig. 3. Schematic presentation of force (newtons) and SSC (\%) means for three maturity stages, green, firm-ripe 3, and tree-ripe, for B11 selection peaches. (Variables measured $\approx 70^{\circ} \mathrm{S}$ are plotted at $-60^{\circ}$ to spread the points for better visibility).

Table 2. Contrasts of force (N) and SSC (\%) between various coordinates and regions around 'Elberta Queen' peach fruit.

\begin{tabular}{|c|c|c|c|c|c|}
\hline \multirow[b]{2}{*}{$\begin{array}{l}\text { Coordinates } \\
\text { contrasted }\end{array}$} & \multicolumn{5}{|c|}{ Maturity stage } \\
\hline & Immature & Green & $\begin{array}{l}\text { Firm- } \\
\text { ripe } 3\end{array}$ & $\begin{array}{l}\text { Firm- } \\
\text { ripe } 4\end{array}$ & $\begin{array}{c}\text { Tree- } \\
\text { ripe }\end{array}$ \\
\hline \multicolumn{6}{|l|}{ Force $(\mathrm{N})$} \\
\hline $90^{\circ} \mathrm{E}-\mathrm{W}$ vs. sutures ${ }^{z}$ & NS & NS & NS & NS & $*$ \\
\hline $90^{\circ} \mathrm{E}-\mathrm{W}$ vs. midribs & NS & NS & NS & $* *$ & $* * *$ \\
\hline $90^{\circ} \mathrm{N}$ vs. all ( - cheeks) & NS & $* *$ & $*$ & $*$ & NS \\
\hline $70^{\circ} \mathrm{S}$ vs. $45^{\circ} \mathrm{N}$ lat. & NS & NS & $* * *$ & $* * *$ & $* * *$ \\
\hline $0^{\circ}$ vs. $70^{\circ} \mathrm{S}$ lat. & $*$ & $*$ & $* * *$ & $* * *$ & $* * *$ \\
\hline \multicolumn{6}{|l|}{$\operatorname{SSC}(\%)$} \\
\hline $90^{\circ} \mathrm{E}-\mathrm{W}$ vs. sutures & NS & NS & NS & NS & NS \\
\hline $90^{\circ} \mathrm{E}-\mathrm{W}$ vs. midribs & NS & NS & $* *$ & $* *$ & NS \\
\hline $90^{\circ} \mathrm{N}$ vs. all ( - cheeks) & NS & NS & NS & $*$ & NS \\
\hline $70^{\circ} \mathrm{S}$ vs. $45^{\circ} \mathrm{N}$ lat. & NS & NS & NS & NS & NS \\
\hline $0^{\circ}$ vs. $70^{\circ} \mathrm{S}$ lat. & NS & $* *$ & $* * *$ & NS & NS \\
\hline
\end{tabular}

${ }^{2}$ Region or coordinate having highest means are presented first. Ns, $* *, * *, * * *$ Nonsignificant or significant at $P=0.05,0.01$, or 0.001 , respectively.

than 'Elberta Queen'. The force required at $90^{\circ} \mathrm{E}-\mathrm{W}$ (cheek regions) was higher than at $10^{\circ} \mathrm{E}-\mathrm{W}$ (sutures) in B11 (Table 3). The B11 was also firmer at $90^{\circ} \mathrm{N}$ than at other coordinates (except cheeks) in the green and shipping stages. The data indicate that 'Elberta Queen' remained firmer at the cheek regions than at areas of the midrib, near the tip, and the stem end. B11 sutures were softer than cheek regions, and the difference occurs at an earlier maturity stage than it did in 'Elberta Queen'. The apex of both cultivars was firmer than coordinates other than the cheeks. There appears to be a difference in force patterns of the cultivars. A cultivar that is uniformly firm between coordinates would be most desirable for shipping and processing.
Table 3. Contrasts of force $(\mathrm{N})$ and $\operatorname{SSC}(\%)$ between various coordinates and regions around B11 selection peach fruit.

\begin{tabular}{|c|c|c|c|c|c|}
\hline \multirow[b]{2}{*}{$\begin{array}{l}\text { Coordinates } \\
\text { contrasted }\end{array}$} & \multicolumn{5}{|c|}{ Maturity stage } \\
\hline & Immature & Green & $\begin{array}{l}\text { Firm- } \\
\text { ripe } 3\end{array}$ & $\begin{array}{l}\text { Firm- } \\
\text { ripe } 5\end{array}$ & $\begin{array}{c}\text { Tree- } \\
\text { ripe }\end{array}$ \\
\hline \multicolumn{6}{|l|}{ Force $(\mathrm{N})$} \\
\hline $90^{\circ} \mathrm{E}-\mathrm{W}$ vs. sutures ${ }^{z}$ & $*$ & $* *$ & $* * *$ & $* *$ & $* * *$ \\
\hline $90^{\circ} \mathrm{E}-\mathrm{W}$ vs. midribs & NS & NS & NS & NS & $* * *$ \\
\hline $90^{\circ} \mathrm{N}$ vs. all ( - cheeks) & NS & $*$ & $*$ & $*$ & NS \\
\hline $70^{\circ} \mathrm{S}$ vs. $45^{\circ} \mathrm{N}$ lat. & NS & NS & NS & NS & NS \\
\hline $0^{\circ}$ vs. $70^{\circ} \mathrm{S}$ lat. & NS & NS & NS & NS & NS \\
\hline \multicolumn{6}{|l|}{$\operatorname{SSC}(\%)$} \\
\hline $90^{\circ} \mathrm{E}-\mathrm{W}$ vs. sutures & NS & NS & $* * *$ & $* * *$ & $*$ \\
\hline $90^{\circ} \mathrm{E}-\mathrm{W}$ vs. midribs & NS & NS & $*$ & *NS & NS \\
\hline $90^{\circ} \mathrm{N}$ vs. all ( - cheeks) & NS & NS & NS & $*$ & NS \\
\hline $70^{\circ} \mathrm{S}$ vs. $45^{\circ} \mathrm{N}$ lat. & NS & NS & NS & $*$ & NS \\
\hline $0^{\circ}$ vs. $70^{\circ} \mathrm{S}$ lat. & NS & NS & $*$ & $* *$ & NS \\
\hline
\end{tabular}

${ }^{2}$ Region or coordinate having highest means are presented first. NS, $, * *, * * *$ Nonsignificant or significant at $P=0.05,0.01$, or 0.001 , respectively.

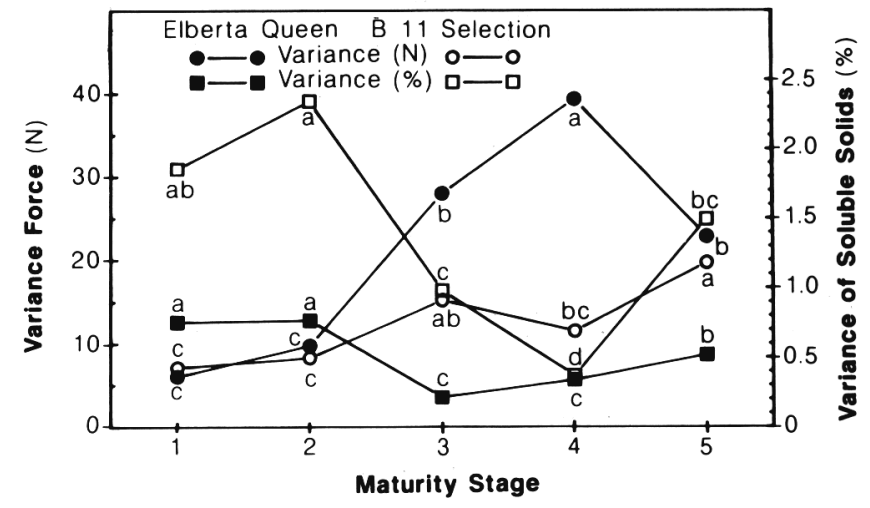

Fig. 4. Variance of force (newtons) through the pared flesh and SSC (\%) changes with maturity stages of peaches. Means of 16 coordinates around five peaches in each maturity stage. Maturity stage: 1 = immature, 2 = green, 3 = firm-ripe (color chip \#3), 4 = firmripe (color chip \#5), and $5=$ tree-ripe. Variance means within cultivar and variable separated by LSD at $P=0.05$ based on analysis of the (variance +1 ) transformed to $\log _{10}$.

Differences in SSC between coordinates were fewer than were force differences in both cultivars. The SSC in 'Elberta Queen' (Table 2) was higher in the $90^{\circ} \mathrm{E}-\mathrm{W}$ than in the $180^{\prime}$ (midrib) coordinates in the firm-ripe fruit and higher in lat. 0" than in $70^{\circ} \mathrm{S}$ in the green and firm-ripe 3 stages. Differences in SSC for B11 (Table 3) generally occurred in the firm-ripe stages 4 and 3.

Variance of force between fruits for a harvest has been reported by Sims et al. (1972) to be an index for measuring the stage of maturity for the crop, and so was used as an index by Stembridge et al. (1972). Variance of force within harvests generally increase as the crop matures, peaks at the firm- to processing-ripe stages, then decreases as more and more fruit become soft-ripe. Variance of force within fruit at the maturity stages selected for this experiment showed the same patterns. Variance means for force among coordinates (Fig. 4) within the maturity stages increased to the firm-ripe 3 stage, and generally remained high during the firm-ripe 4 and through the tree-ripe stages of B11. Variance of force for 'Elberta Queen' decreased at the tree-ripe stages. Variance for SSC was low (Fig. 4). It diminished as maturity progressed to the firm-ripe stages. The SSC 
became more uniform in the shipping stage fruit when final swell neared completion. Variance of SSC for B11 was about twice that for 'Elberta Queen'.

Color measurements, as used by Delwiche and Baumgardner (1983, 1985), were not available to correlate with force and SSC. There were no significant correlations between SSC and force across coordinates. The $10 \mathrm{x}-\mathrm{y}$ pairs were too few for dependable correlations between SSC and force at lat. $90^{\circ} \mathrm{E}-\mathrm{W}$ with long. 0", the coordinate at which previous correlations are reported.

Although these data may not become an index for harvesting peaches at the firm-ripe or shipping stage, force appears to be useful at coordinates in evaluating cultivars for uniform ripening. The technique using the small probe is also expected to be capable of measuring the effect of the skin on bruising and shipping quality. Since the probe damages a small area of tissue, better correlations might be made between color and force to provide a better index of maturity range at which to make a once-over harvest. The technique is expected to be most valuable in evaluating new cultivars for fruit uniformity, treatment effects in research, and maturity range for once-over harvests.

\section{Literature Cited}

Baumgardner, R.A., G.E. Stembridge, L.O. Van Blaircom, and C.E. Gambrell, Jr. 1972. Effects of succinic acids 2,2-dimethyl hydrazide on the color, firmness, and uniformity of processing peaches. J. Amer. Soc. Hort. Sci. 97:485-488.

Blake, M.A. and O.W. Davidson. 1936. Some studies of the degree of maturity of peaches at harvest in relation to flesh firmness, keeping quality, and edible texture. N.J. Agr. Expt. Sta. Bul. 606.

Byers, R.E. and F.H. Emerson. 1969. Effects of succinamic acid 2,2- dimethyl hydrazide (Alar) on peach fruit maturation and tree growth. J. Amer. Soc. Hort. Sci. 94:641-645.

Delwiche, M.J. and R.A. Baumgardner. 1983. Ground color measurements of peach. J. Amer. Soc. Hort. Sci. 108:1012-1016.

Delwiche, M.J. and R.A. Baumgardner. 1985. Ground color as a peach maturity index. J. Amer. Soc. Hort. Sci. 110:53-57.

Gambrel], C.E., Jr., W.H. Rhodes, and E.T. Sims, Jr. 1967. Some effects of four growth regulators on thinning, yields, size and maturity of Ranger peaches when applied for one year and two years in succession. S.C. Agr. Expt. Sta. Res. Ser. 101.

Horton, B.D. 1973. Training peach trees for mechanization. Ark. State Hort. Soc. 84th Annu. Meeting. p. 93-96.

Horton, B.D. 1985. Training peaches for completely mechanized production. HortScience 20:244-246.

Peterson, D.L., R. Scorza, S.S. Miller, and D.M. Glenn. 1989. Evaluating fresh-market peaches for once-over mechanical harvesting. HortScience 24:446-448.

Sansavini, S., J-M. Martin, and K. Ryugo. 1970. The effect of succinic acid 2,2-dimethyl hydrazide on uniform maturity of peaches and nectarines. J. Amer. Soc. Hort. Sci. 95:708-711.

Sims, E.T., Jr., W.P. Byrd, and C.E. Gambrell, Jr. 1972. The use of individual fruit (intraplot) variance as a technique to evaluate peach fruit uniformity. J. Amer. Soc. Hort. Sci. 97:285-287.

Steel, R.G.D. and J.H. Torrie. 1960. Principles and procedures of statistics. McGraw-Hill, New York.

Stembridge, G.E., R.A. Baumgardner, W.E. Johnson, and L.O. Van Blaircom. 1972. Measuring uniformity of peach maturity. HortScience 7:387-389.

Tyson, B.L., G.G. Dull, and B.K. Webb. 1975. A method for selecting the optimum maturity distribution for mechanical harvesting of clingstone peaches for processing. HortScience 10:237-238.

Webb, B.D., C.E. Hood, W.H. Jenkins, and C.D. Veal. 1973. Development of an over-the-row peach harvester. Trans. Amer. Soc. Agr. Eng. 16:450-455.. 